\title{
Viral hepatitis: a challenge for nursing
}

\author{
Sheila Araújo Teles' \\ ' Universidade Federal de Goiás, School of Nursing. Goiânia, Goiás, Brazil.
}

\begin{abstract}
How to cite this article:
Teles SA. Viral hepatitis: a challenge for nursing. Rev Bras Enferm [Internet]. 2017;70(2):231-2. DOI: http://dx.doi.org/10.1590/0034-7167.2017700201
\end{abstract}

The 20th century unveiled the mystery of the etiology of viral hepatitis, with the identification of five different agents responsible for these infections: the hepatitis A virus (HAV), hepatitis B virus (HBV), hepatitis C virus $(\mathrm{HCV})$, hepatitis $\mathrm{D}$ virus (HDV), and hepatitis $\mathrm{E}$ virus (HEV). These viruses account for one million deaths every year. HBV, HCV and HDV cause acute and chronic hepatitis, cirrhosis and hepatocellular carcinoma, whereas HAV and HEV cause self-limited liver disease. More recently, cases of chronic hepatitis $E$ have been reported in transplant patients. Also, the risk of fulminant hepatitis is greater among pregnant women.

The creation of the HBV vaccine in 1981 and the gradual adoption by World Health Organization Member States have contributed to reducing this infection among humankind ${ }^{(1)}$. In addition to the vaccine, the availability of antiviral drugs to treat chronic hepatitis B has reduced the burden of this disease. Considering that HDV is defective and depends upon HBV for replication and maintaining itself in the host cell, it has also presented a downward trend in countries that adopted the HBV vaccine.

In 1989, the discovery of the hepatitis C virus shed light on most non-A non-B post-transfusion hepatitis. With the implementation of HCV screening in blood banks, there was a significant reduction in the risk of posttransfusion hepatitis C. Currently, injection drug users are at the highest risk for this infection and are potential sources of transmission to the population at large. Despite the absence of a vaccine against hepatitis $\mathrm{C}$, there are new antiviral drugs capable of eliminating the virus. However, access to treatment is still limited in several parts of the world.

The betterment of the population's living conditions, reflected by access to treated water and basic sanitation, has reduced the prevalence of hepatitis $\mathrm{A}$ and contributed to lowering the burden of this infection in developing countries such as Brazil. In these countries, it is suggested that children be vaccinated against hepatitis A. Curiously, a greater challenge will reside in the increased demand for health services to treat such cases, as now they will emerge at later stages of life, when the clinical symptoms of hepatitis A are more frequent. More recently, a vaccination against hepatitis E was made available; however, its supply is still limited to some Asian countries.

Despite all of these advances, viral hepatitis is still a great public health threat. Poverty and lack of access to health services contribute to maintaining these diseases. The World Health Assembly has systematically expressed concern over viral hepatitis. In 2010, the $63^{\text {rd }}$ World Health Assembly adopted resolution WHA63.18, in which it called on Member States to promote cost-effective approaches to prevent, control and manage viral hepatitis, in addition to establishing July 28 as World Hepatitis Day.

Some years later, recognizing the need to intensify and expand the response to hepatitis, the $67^{\text {th }}$ World Health Assembly, via resolution WHA67.6 de 2014, requested the necessary technical support for Member States to develop solid national viral hepatitis prevention, diagnosis and treatment strategies with time-sensitive goals. In response to this resolution, the World Health Organization initiated its global health sector strategy on viral hepatitis 2016-2021, which included measures for eliminating viral hepatitis B and C as a public health threat by 2030, thus corroborating the United Nations 2030 Agenda for Sustainable Development.

Brazil has responded to these global demands, and nursing has permeated all of the control and prevention actions for these infections, whether by implementing viral hepatitis surveillance systems, which allow us to monitor trends; planning prevention and control strategies; conducting clinical screening at blood banks of 
potential blood and blood products; administering vaccinations and working in immunization campaigns; providing prenatal care and preventing vertical transmission; tracking individual cases of viral hepatitis; working in tertiary care with individuals affected by acute and chronic infections; or producing knowledge to conduct safe evidence-based practices.

Currently, Brazil has low endemicity of hepatitis B and C, and medium endemicity of hepatitis $A^{(2)}$. However, the greatest burden of these infections falls upon impoverished populations, and/or those with greater social and individual vulnerabilities, such as illicit drug users, sex professionals, homeless people, and homosexuals. In general, these subgroups have limited access to public health services, and nursing can contribute to identifying these populations and help interrupt the chain of infection and achieve the audacious goal of eliminating these viruses from our planet, through prevention, health promotion and control.

\section{REFERENCES}

1. Ott J, Stevens GA, Groeger J, Wiersma ST. Global epidemiology of hepatitis B virus infection: new estimates of age-specific HBsAg seroprevalence and endemicity. Vaccine[Internet]. 2012[cited 2016 Dec 10];30(12):22129. Available from: https://www.clinicalkey.com/service/content/pdf/watermarked/1-s2.0-S0264410X11020779. pdf?locale $=$ pt_BR

2. Pereira LMMB, Ximenes RAA, Moreira RC. Estudo de prevalência de base populacional das infecções pelos vírus das hepatites A, B e C nas capitais do Brasil[Internet]. Recife: Universidade Federal de Pernambuco; 2010[cited 2016 Dec 10]. 295 p. Available from: http://www.aids.gov.br/sites/default/files/anexos/publicacao/2010/50071/ estudo_prevalencia_hepatites_pdf_26830.pdf 